\title{
The Divide Over European Security
}

\section{D. Van Aller *}

\section{Introduction}

The war in Iraq continues to divide the Western democracies, nations once optimistic that the post-Cold War environment might lead to a more secure world. Even if solutions proved difficult to achieve, many hoped that these societies would share common viewpoints on threats to peace. Yet there have been contrasting security perspectives that have been highlighted by the conflict in Iraq, such as that of former European Union High Commissioner for Foreign and Security Policy Javier Solana, who stated in 2003 that "Europe is not at war." One of the main cleavages is between Europe and the United States generally, with the former considering that the U.S. has increasingly been too dedicated to the unilateral use of force, views held by both elites and the general public in Europe. Even before the Bush Administration, Samuel Huntington described U.S. foreign policy as one of "world unilateralism," with a single-minded devotion to its own interests while minimizing those of other countries. ${ }^{1}$ Since the Iraq war, Harold Pinter has stated, the U.S. "has become a fully-fledged, award-winning, gold-plated monster. It has effectively declared war on the world....” Many people in Western Europe have some sympathy with this view, if not its hyperbolic quality, and the war in Iraq appears to have amplified long-held convictions about the world's sole remaining superpower. ${ }^{2}$

However another great cleavage is within Europe itself, mainly between those countries once dominated by the former Soviet Union and others more willing to object to U.S. security proposals. The major Central European states have long been part of the operations in Iraq, despite opposition and even outright threats by their new European Union neighbors. French President Chirac, for instance, publicly chided Poland for its quick support of the war, and as EU negotiations loomed implied that only major powers should decide questions of war and peace. ${ }^{3}$ Poland and the Czech Republic are presently being courted by the United States as sites for future missile defense bases, part of a system called "Son of Star Wars" by their media.

As of March 2007, Deputy Assistant Secretary of State Mark Pelaka was consulting with Europeans on plans to erect a partial shield against ballistic missiles launched

\footnotetext{
* Christopher D. Van Aller is professor of political science at Winthrop University in Rock Hill, SC, where he specializes in international relations, security policy, European politics, and post-Soviet politics.

1 Samuel Huntington, “The Lonely Superpower,” Foreign Affairs 78:2 (March-April 1999): 35-49.

2 Cited in Steven Brooks, As Others See Us (Peterborough, Ont.: Broadview Press, 2006), 107. Brooks documents abundant evidence of anti-American attitudes in Europe, even in those countries in the "Coalition of the Willing," such as the United Kingdom.

3 Transcript of interview with Jacques Chirac, New York Times Online (22 September 2003).
} 
from Iran or North Korea, or perhaps an unauthorized launch from Russia. The plan would include up to ten ground-launched ballistic missiles in Poland, and the Czech Republic would have a large radar array to track incoming missiles, costing about USD 1.6 billion. Just as in earlier disagreements on Iraq, Western European governments (and their citizens) are objecting to these plans. Thus, German Foreign Minister Steinmeier has warned of a new Cold War because of strident Russian objections, and has called on all NATO partners to agree on the bases before implementation. ${ }^{4}$ Another European diplomat echoed Chirac's remarks on Iraq when he stated that the Central Europeans failed to see that their agreement "was a national decision with European implications." 5

Once again, the current U.S. administration appears to be pitting the "New Europe" against the old, revealing a strategy to "cherry pick" allies for missions that some consider destabilizing and destructive of a common approach to security. This Central European anti-missile deployment could potentially have more consequential ramifications for the United States' standing in Europe than the conflict in Iraq. While Russia rejected calls for preemptive war, and threatened to veto the final UN resolution authorizing the use of military force in Iraq, its reaction to the limited ballistic missile defense emplacements has been quite extreme. In a strident speech before key local elections in March 2007, President Putin stated that such measures "could provoke nothing less than the beginning of a [new] nuclear era," and that the United States had "overstepped its national borders in every way." 6 While the contributions to the effort in Iraq have been far from easy for Eastern European states, despite very low casualties, this current controversy has the potential to inflame European relations from the Atlantic to the Urals. As of 2001, before anti-American sentiments were exacerbated by the war in Iraq, a majority of the populations of Germany (90 percent), France (86 percent), Italy (76 percent), and Great Britain (80 percent) were opposed to the prospect of such bases, echoing the fears caused by Reagan-era nuclear policies in the early 1980s. ${ }^{7}$

There are essential questions that require exploration to begin to understand this apparently small-scale proposal, as it has wide-ranging political dimensions. For one, is there a legitimate need for such arrangements? Does it make sense to counter the weapons of new nuclear powers (NNP) or terrorists in this way? Related to this is the idea that some Europeans are reflexively opposed to active security measures, for reasons other than objective strategic criteria. Conversely, missile defense proponents seem to place a form of technological faith in these theoretical measures.

Next, are Russian fears indicative of a genuine anxiety about an overly assertive United States, or are they perhaps a smoke screen for Russia's forcible reassertion of

4 William Kole, "U.S.: Defense Shield No Threat to Russia," Associated Press (23 March 2007).

5 “Russia Raises Stakes Over U.S. Plan for Missile Shield,” The Independent Online (U.K.) (20 February 2007).

6 “Putin Lashes Out at U.S. Foreign Policy,” St. Petersburg Times Online (13 February 2007).

7 Pew Global Attitudes Survey Report, 8 August 2001; available at http://pewglobal.org/ reports/print.php?ReportID=5. 
control in its sphere of influence? Then again, Russian pronouncements may be primarily intended for domestic consumption, drawing on old fears of Western encirclement. Why are the Eastern Europeans so willing to differ with their wealthy EU trading partners in the West, but also with a more powerful Russia that has (among other considerations) control over essential energy supplies? Lastly, is this development one more indication that plans for a common European policy on security are overly optimistic, destroyed either by a cynical United States or by the fundamentally different viewpoints of its diverse members?

\section{Ballistic Missile Defense}

Ever since the controversial proposals in the 1980s for a large-scale system to simultaneously destroy several thousand Soviet ICBMs, the idea of stopping at least some missile attacks has been retained by Americans resistant to the depressing realities of the doctrine of "mutually assured destruction" (MAD). For example, Republican conservatives in Congress promoted the Defend America Act in 1996 that called for a "heavy” Ballistic Missile Defense (BMD) system by 2003, which was resisted by the Clinton Administration due to considerations of Russian, Chinese, and European reactions. Even the use of the word "heavy" harks back to memories of the deterrencechallenging "Star Wars" system originally proposed by President Reagan, and the legislation refers to the system's eventual expansion to protect all of the United States. Once in charge, the second Bush Administration made missile defense its major strategic emphasis, with Donald Rumsfeld, the prominent former chairman of a pro-BMD commission installed as Secretary of Defense, as its chief proponent.

The pros and cons of the original Strategic Defense Initiative cannot be discussed here, but questions of the system's cost, practicality, and counter-measures were never sufficiently answered before the end of the Cold War. Other considerations concerning the fate of long accepted arms treaties and assumptions about deterrence were also unclear and potentially alarming to both friends and foes alike. In terms of the current controversy, the idea is that since technology-particularly the ability to better target the slower boost phase of missiles, or the initial portion of their flight-has improved so much since the 1980s, the feasibility of stopping weapons in flight has increased greatly. In actuality there has not been a successful test of a missile intercept since 2002, and even then under questionable test scenarios, yet proponents consider even an imperfect system better than no alternative at all. Just as Western Europeans have an unwavering faith in non-military solutions, BMD advocates seem willing to suspend disbelief as well. Perhaps a future system could shoot down several missiles, but in 
turn why would a potential opponent rely on the one technology for which there is a defense? ${ }^{8}$

Most importantly, the threat from non-traditional sources has become more severe in the view of anti-missile system advocates. Brian Kennedy asks, "What if Osama Bin Laden were to obtain a nuclear ballistic missile from Pakistan (which, after all, helped to install the Taliban regime), [and] placed it on a ship somewhere off our coast...?”9 The question of how to address the simpler, alternative delivery systems possible for such weapons remains unanswered, so the administration's most likely opponents remain Iran and North Korea, both of whom have evidenced capabilities in both ballistic missile technology and more ominously, in nuclear capabilities. President Ahmadinejad's frequent calls for the destruction of Israel and his vows to continue Iran's nuclear programs are examples of this willingness to risk conflict. ${ }^{10}$

The Bush Administration's view is that these regimes are untrustworthy, and both may be less predictable in terms of their assumptions about deterrence than was the Soviet Union. Moreover, they could use third parties—such as terrorist groups-to deploy their weapons in unconventional means, which would render the threatened retaliation necessary to make MAD work much more problematic. The question of responsibility would be unclear. It should also be mentioned, however, that proponents of this "limited" system imply that it should be expanded at some point, to approximate the Strategic Defense Initiative of a generation ago. For example, former CIA analyst William Lee and others consider that Russia still deploys such a system around Moscow, exploiting a provision in the ABM Treaty, with the capability of protecting 75 percent of the Russian population. The United States and its allies therefore have a right to deploy such systems. ${ }^{11}$ Thus, arguments about the benefits and liabilities of a large-scale missile defense capability are not over, and underlie some of the suspicions about the current system. Any mention of limited ballistic missile defense implies a possibility of an eventual return to SDI, with its challenge to standard interpretations of deterrence.

Western European governments are alarmed over statements such as that of Lieutenant General Trey Obering, the Pentagon's current Missile Agency head, when he uses phrases such as "technology has caught up with the vision," literally using words

8 David Duma, the Pentagon's chief weapons tester, said in 2006 that, "there is insufficient evidence to support a confident assessment of [even] limited defensive operations." "Director Operational Test and Evaluation FY 2005 Report” (January 2006), cited in Center for Arms Control and Non-Proliferation, The Illusion of Operational Readiness of National Missile Defense (7 July 2006), 2.

91 January 2002; the speaker is head of the influential Claremont Institute; text of the cited speech is available at www.missilethreat.com/publications/id.653/pub_detail.asp.

10 As of this writing, the Iranian seizure of British sailors enforcing United Nations mandates continues, a further indication of the regime's irresponsibility. According to former Foreign Secretary Malcolm Rifkind, the EU has revealed yet again its weakness on security policy.

${ }^{11}$ Ibid. Lee has written a book that is influential with missile defense proponents, titled The ABM Treaty Charade: A Study in Elite Illusion and Delusion (Washington, D.C: Council for Social and Economic Studies, 1997). 
from a Reagan speech justifying SDI in $1983 .{ }^{12}$ With the notable exception of Great Britain, major Western European governments reject missile defense if selectively imposed by the United States, echoing their earlier sentiments when it was the main issue before the Atlantic Alliance before the events of 11 September 2001. While an exploration of such a system is not unpalatable to these governments, in contrast to the Iraq operation, the unilateral method of implementation is at least as offensive to them. At one meeting of EU foreign ministers, the Luxembourg delegate called the Bush BMD proposal "incomprehensible," and went on to state, "We'll have no stability in Europe if we force Russia into a corner." ${ }^{\prime 3}$ In this sense, there is concern that the heavy-handed manner of implementation is seen as alarming to the Russians, as well as about the system's long-term strategic implications. Of course, the capability to knock down up to a dozen or so missiles, however imperfectly, should not objectively change the strategic balance in Europe to any degree, so the argument may be more deeply philosophical in nature on the part of the "Venusian" Europeans.

In his controversial book Of Paradise and Power, Robert Kagan notes a philosophical "security divide" between much of Europe and the United States. He thinks the former is unwilling to contemplate war, is reluctant to fund defense, and is reliant on international laws and treaties for security. Even small uses of force, such as the intervention in Kosovo, revealed a huge gap in capabilities and a lack of coordination between the United States and its European allies. In an ironic reversal of the isolationist 1930s years, it is now the U.S. that is willing to confront threats, who rejects much of normative international law, and feels empowered to radically alter long-term arrangements, such as the ABM Treaty. ${ }^{14}$

Other commentators, such as Wayne Merry, feel that longtime superpower security guarantees have made the Europeans all too confident that problems can be solved without at least the possibility of force. He goes as far as to say that a dissolution of NATO might teach Europe that active measures, particularly in the "second tier" of less-developed countries, are necessary to protect the West and convince all to share the expense of security burdens with the United States. The "Martian" superpower has erred as well, in that treating its allies like a "toolbox" reduces alliance cohesion; weaker members in particular resent being treated primarily as a means to an end. ${ }^{15}$ As Strobe Talbott has written, this administration has surpassed its predecessors in its willingness to pursue unilateral options that use diplomacy as a means to single ends rather than as a series of limiting compromises. ${ }^{16}$

12 “Intercept or Interfere,” The Financial Times Limited Online (7 March 2007), 2.

13 Ibid.

14 Robert Kagan, Of Paradise and Power (New York: Alfred A. Knopf, 2003), 1-8.

15 E. Wayne Merry, “Therapy’s End: Thinking Beyond NATO,” The National Interest (Winter 2003): 1-7.

16 Strobe Talbott, "Memo to America: Join the World," www.theinterdependent.org (Spring 2007). 


\section{The East-West Divide in Europe}

There are some European leaders who feel that missile defense is worthwhile, and hope that arguments about it do not further split the Alliance after the agony of Iraq. NATO Secretary General Jaap de Hoop Scheffer has pointed out the need to be objective on the question, and in particular to resist the temptation to appeal to short-term domestic constituencies. In his words, "Let's not use false arguments. Let's use real arguments" in response to pronouncements from the German Social Democratic Party that no such system should ever be deployed. ${ }^{17}$ He points out that NATO has agreed to explore missile defense (in an exhaustive 10,000-page study), and accepts that the threats are indeed real and growing. Iran and North Korea have repeatedly demonstrated alarming capabilities in his view, and the choice of Eastern Europe is a cost-effective one, given that radar capabilities located there will easily cover most of the Continent. ${ }^{18}$ Nonetheless, Western European constituencies see NATO as a vehicle to subsume their interests before those of a unilateralist superpower, and these feelings have increased support for an EU defense and foreign policy independent of U.S. direction. ${ }^{19}$ Exacerbated by events in Iraq and scandals like the treatment of prisoners at Guantanamo, European citizens increasingly reject any sort of U.S. leadership.

In a significant departure, Javier Solana, now head of the European Defense Agency, has cautioned that such systems must only be installed if, first, they do not negatively affect the organization's "relations with third countries, namely Russia” and second, that such a decision-if made unilaterally by Central European nationswould weaken the solidarity of the Union. He feels that sovereignty cannot be used to transcend community interests in continental security. ${ }^{20}$ The contrast between his notions of security with that of the head of NATO is instructive, as it reveals that the two organizations have different agendas and contrasting interpretations of security. Certainly the second pillar of the Maastricht Treaty, calling for a common security policy, seems in doubt. Leftist members of the European Parliament have been much more outspoken against the bases, and have been countered by conservative members from Eastern Europe, with one stating, "the missile defense shield is not the danger; the danger is a number of member states adopting the Russian view."21 Poland and the Czech Republic are now full and established EU members, in contrast to their status during the earlier debate over Iraq in 2003, and so their willingness to depart from EU admonitions is a further blow to common policy.

17 “NATO Chief Defends U.S. Missile Plan,” The Telegraph Online (U.K.), (20 March 2007).

18 “NATO Chief Warns of Division over U.S. Missile Shield Plans,” EU Observer.com (12 March 2007).

19 Leonard Ray and Gregory Johnson, "European Anti-Americanism and Choices for a European Defense Policy,” Political Science (January 2007): 89.

20 "EU's Solana: Participation in U.S. Missile Defense Shield Must not Harm EU Security," Pravda Online (29 March 2007).

21 “European Parliament Debates Missile Plan,” International Herald Tribune Online (29 March 2007). 
While the leadership of Germany in particular is now more centrist, and is attempting to heal the Alliance after the anger over Iraq, it must pay attention to its alarmed constituents and fellow EU member nations. Even German Chancellor Angela Merkel's own party supporters are questioning the missile deployments and are close to the Social Democrats on this issue. Christian Democratic Union legislator Ruprecht Polenz has advised Merkel "to insist that the Europeans unite on a common position ... bilateral arrangements of individual member states make such agreement increasingly difficult.... Everything [should be] in favor of being very transparent towards the Russians." 22 Other legislators from the SPD and the Greens have been predictably more outspoken, with the latter insisting that the system is actually designed to eventually marginalize the Russian deterrent.

The new chancellor is determined to heal the rift caused by the Iraq war, and in particular by her predecessor's willingness to criticize the U.S., but the pressures on her are substantial. Germany's new position as head of the EU Council demands that it take a leadership position in resolving this controversial issue, and it must not appear as being either pro-U.S. or anti-Russian. To this end, Merkel has called for full NATO agreement before implementation. To add another complication, Germany looks to Moscow for ongoing energy supplies, and may even build a pipeline that avoids troublesome Poland. ${ }^{23}$ The Bush Administration does not seem interested in exhaustive consultation with those European nations that are not involved in hosting the new bases. According to U.S. Ambassador to NATO Victoria Nuland, the Allies would be informed of "important decisions" but a "public announcement" of the plans is not foreseen. ${ }^{24}$

For his part, President Chirac, in his final months in office, was nevertheless very critical about the chance that the new bases would weaken European security cohesion. His main concern was that relations with Russia would be damaged, starting a new Cold War and creating "a new dividing line in Europe." 25 These considerations must be added to ongoing French objections to U.S. attempts to restructure the NATO Alliance by partnering with new non-European states like Japan and Australia, countries that have contributed to the Iraq war effort. ${ }^{26}$ Neo-conservatives like Paul Wolfowitz have written of the importance of "demonstrating that your friends will be protected ... and those who refuse to support you will live to regret doing so...."27 Again, as in the earlier Iraq debate, France is wary that the U.S. is continuing to divide the Alliance by

22 “Missile Defense Puts Merkel on Defensive,” Der Spiegel Online (6 March 2007), 5.

23 Martin Zaborowski, “A Feud Berlin and Warsaw Must End,” The Financial Times.com (19 January 2007), 1.

24 Nuland's statement on 23 January 2007; “Blair Seeks British Role in US Missile Defence,” Financial Times.com (24 February 2007).

25 “Chirac Hits at U.S. Missile Plans,” Financial Times.com (10 March 2007).

26 “France Accused of 'Provocation' at NATO Summit amid 'Bitter Fight' with Washington," Le Figaro (cited in Open Europe, 29 November 2007).

27 Thomas Ricks, "Planning for War," The Washington Post (National Weekly Edition) (12 January 2003), 8. 
utilizing newer members, and is thereby diluting Western European influence in security deliberations. Poland, the Czech Republic, and others of course were lauded as the "new Europe" by an undiplomatic Secretary Rumsfeld. Chirac publicly chided the Eastern Europeans for damaging Europe in the famous Vilnius letter, and despite his harshness still considers that the "European spirit demanded [consultation] with other members before making such an important decision that engages all of Europe.”28

There is also a European alternative to BMD that is less destabilizing because it relies on deterrence. France has promised nuclear retaliation against attacks from countries like Iran, and there is some support from European publics on a firm stand against this outspoken and unpredictable country. ${ }^{29}$ Chirac's defense minister stated, after some criticism of this idea, that such weapons had to have some possibility of use to mean anything, especially against powers with relatively few weapons. More importantly, deterrence is the main conventional alternative to ballistic missile defense, as even the small nuclear forces in Europe dwarf that of any future threat from the Middle East. ${ }^{30}$ While Chirac's successor Nicolas Sarkozy appears less stridently anti-American, even he will have to pay attention to the fact that the EU is worried about Russian relations and energy supplies. Moscow's willingness to both raise prices and turn off the spigot on its natural gas pipelines, even to relative brethren like Belarus in 2006, cannot be lost on an energy-dependent Europe. These harsh methods not only substantially increased revenue to Moscow, but also deepened its long-term control of gas supplies to the Continent. ${ }^{31}$

\section{The Central European Perspective}

As was the case in the controversy over involvement in Iraq, Poland in particular is very much at the geographical and political center of a key security debate. This historically vulnerable nation has been massively damaged, and at times destroyed as a country, in the competition between its larger neighbors. In the twentieth century alone, it has felt abandoned in times of impending danger or domination. It therefore is wary of relying on those countries that eschew war as a possibility in foreign relations. The Czechs have had a similar interwar experience, as well as having suffered postwar domination by the Soviet Union. The war in Iraq became the first major case for conflicting interpretations of security by Western democracies since the end of the Cold War. If a finally independent Poland sided with defiant Western Europeans in this conflict, it would have placed its faith in long-term and heretofore unrealized plans for a unified European defense policy. Conversely, its decision to side with its new EU neighbors would perhaps grant it new political and economic influence, as linkages

28 “French President Admits Failure on Constitution,” Financial Times.com (9 March 2007).

29

According to a poll released on 4 April 2007, 52 percent of EU citizens agreed that military action was justifiable to stop states like Iran from acquiring nuclear weapons. A majority agreed in eighteen states, while a majority in nine disagreed; see openeurope.org.

30 "French Defense Minister Calls Chirac's Warning of Nuclear Response to Attack Necessary,” Associated Press Worldstream (4 July 2006).

31 “Loveless Brothers,” The Economist.com (11 January 2007). 
would deepen over time. In both the Iraq war and in the current divide over BMD, supporting the U.S. view would imply choosing a security approach similar to the shifting realpolitik coalitions of the past, but would also place Poland in alliance with the world's strongest power and its willingness to use force. ${ }^{32}$

On another level, the basic debate is whether the older collective security arrangement, NATO, still has value, given its transatlantic entanglements, or whether an independent European foreign and defense policy can work, particularly when there are radically different perspectives between members. Whether Iraq or BMD are truly the imperatives the United States portrays them as being is not the only issue. For Poland and the Czech Republic, the problem is that both sides of the Atlantic are now more overtly considering the relevance of an organization, NATO, that both hoped would bring these fledgling democracies unprecedented protection and prestige. Former Polish President Kwasniewski admitted in 2004 that the EU was less popular than NATO in his country, because memories of foreign domination are still fresh. As recently as the mid-1990s, policymakers and experts alike had grave reservations about the prospects of these former Warsaw Pact countries joining such an alliance, so its potential obsolescence is therefore a most painful prospect after the intense debate about admission.

Not only is NATO being called into question compared with rival EU alternatives, neo-conservatives in the Bush Administration are resistant to any impediments to U.S. action, and are even more wary of the rise of an eventual EU common security policy. ${ }^{33}$ Poland, the Czech Republic, and potential NATO members think that unless they cooperate with U.S. security measures, even if mistaken or wasteful in terms of the specific policy, then the protective superpower could withdraw substantially from European affairs, leaving their territories once more subject to interference by outside powers (Russia being the main threat, but not the only one). ${ }^{34}$ As a country that has suffered as a result of previous periods of U.S. isolationism, as was the case between the world wars, Poland for one is wary of anything that will lessen transatlantic commitments. As former President Kwasniewski stated, "We know the meaning of indifference at a time of threat, like the indifference Poland experienced in 1939."35

At the same time, Poland must consider the impact of its actions on its European neighbors, as a different sort of security, mainly economic in nature, is vital as well. For centuries, this strategically vulnerable country has had to weigh multiple considerations concerning its allies and enemies. Joshua Spero points out how complex Po-

32 See Elizabeth Pond's account of President Bush's visit to Krakow in 2002, in which he conspicuously never mentioned the EU and talked of traditional Polish ties to the United States. Pond, Friendly Fire: The Near Death of the Transatlantic Alliance (Washington, D.C.: Brookings Institute Press, 2003), 85-6.

33 Ibid., 8-9.

34 Radek Sikorski, “NATO Has not Perished Yet while We Are Still Alive,” American Enterprise Institute for Public Policy Research (2 March 2004), 1-3.

35 "President of Poland Signs a Decision to use Polish Troops outside of Poland," polandembassy.org; dated 17 March 2003, posted 26 February 2004. 
land's situation has been since 2000. It has served the "difficult role as bridge builder between east and west ... [in Europe] while fissures within the Alliance continue to deepen." ${ }^{36}$ On the Continent alone it must reconcile differences between itself and the East, namely Ukraine and Russia, while maintaining good relations with its new EU partners. After initial Iraqi operations, Poland worked to heal the rift between the U.S. and its now more independent allies by reaching out after its involvement to both France and Germany, admitting that the latter nations' reservations about Iraq had merit, and calling for more UN supervision in the operation. However, by its plans to introduce the missile bases, the Bush Administration is again placing its interests over those of a united Europe, and is keeping its allies fragmented in order to dilute opposition to its policies. Whether this is a long-term trend, as some scholars suggest, or just a manifestation of a uniquely independent Washington administration, the nations of Central Europe must make some difficult choices.

Compared with the previous Kwasniewski administration, the current one has tilted more in the direction of the United States and away from the Western Europeans. Just as in the case of Iraq, the Polish people are not in support of missile bases, but nonetheless the new government is showing its independence from its larger European neighbors. From BMD to environmental policy to ongoing commitments in Iraq, Poland is showing its willingness to take its own unique path, something not unknown in its history. ${ }^{37}$ Despite the fact that the Iraq operation is now extending long beyond U.S. predictions, and other longtime allies like the United Kingdom and Hungary are withdrawing their troops, Poland kept its troops deployed in Iraq for a longer period, along with those from other Eastern brethren like the Czech Republic and Lithuania. In short, even when there is substantial political cover to end their involvement, these countries are choosing not to do so, and Poland moreover has increased its contribution to Afghanistan by five times, to one thousand soldiers. This deployment is also in contrast to those of most Western European NATO members, who have refused to contribute troops in an increasingly dangerous environment.

Somewhat surprisingly, Poland has not received much in the way of political or economic benefit from Washington for its sacrifices, which have been substantial for a poor country still recovering from Communist rule. For example, Warsaw now desires to purchase both F-22 and F-18 fighters, but is not deemed a close enough ally by the Pentagon to deserve these systems, despite providing lasting support for an unpopular war. $^{38}$ In the view of some, Central Europe is being used as a means to an end by a distracted and overwhelmed Bush Administration, but the Poles are realistic that their alliance is a pragmatic if thankless one. The Czechs also feel a lack of gratitude by the U.S. for their contributions in Iraq, Afghanistan, and Kosovo, particularly in areas like

36 Joshua B. Spero, “Beyond Old and New Europe,” Current History (March 2004): 135.

37 “Poland Boosts U.S. Ties, Differs from EU,” Associated Press (7 March 2007).

38 "Key to Efficient Polish-American Partnership: No Sentiments, Only Pragmatism,” Rzeczpospolita (23-24 September 2006), A7; Polish News Bulletin (28 September 2006). 
visa requirements, but nevertheless hope that the missile bases will bring eventual concessions. $^{39}$

The Kaczynski Administration is less experienced in foreign policy and "looks out and tends to see the old Germany and the old expansionist Russia; it has not taken part mentally in the long process of [European] integration." 40 More importantly, old memories remain of the United States being far more interested in the "rollback" of communism than the Western Europeans, with the result that Adam Michnik, the Polish writer, considers that his countrymen "tend to be more pro-American than Americans." ${ }^{41}$ Added to the longstanding historical ties between the two nations since the American Revolution, the current government is a more nationalist one that is suspicious of EU weakness on security matters, and is much more willing to confront Russia. While pushing the Western Europeans on ideas like a meaningful EU army, the fact remains that President Kaczynski is very skeptical of theoretical ideas on transnational security and the obsolescence of the nation-state. He is no doubt aware that EU citizens are unwilling, at a rate of about 75 percent, to spend any more on defense, in contrast to Poland, which has steadily increased its defense expenditures and obligations. $^{42}$ The president has therefore stated: "I think the nation-state has still not ended its mission ... and I know that it is very uncomfortable in the Union to be alone, but that does not mean we are afraid of that.” In particular, he is worried that the EU will not be firm enough in dealing with an assertive Russia, on issues ranging from energy supply to trade relations to Moscow's "continuing powerful military." ${ }^{43}$ For these many reasons, Poland has until recently vetoed EU negotiations with Russia on trade.

\section{The Threat from Russia}

Compared to the days of Boris Yeltsin, the actions and statements of President Putin are increasingly threatening to the Central Europeans, and are also more credible, because Moscow is now substantially stronger due to its full national coffers thanks to energy revenues. Russia has demonstrated that it wishes to reassert control in both the near abroad, as witnessed by its interference in the Ukrainian elections, as well as to defend the rights of ethnic kinsmen in places like Kosovo. More alarmingly for regional security, the Russians are starting to expand their nuclear abilities, with former Defense Minister Ivanov calling the START treaty a "Cold War relic," ostensibly because of threats from the new nuclear powers, but signaling as well a rejection of arms control instruments and negotiations with the United States. He also stated that it was

39 “New Foreign Minister Wants Predictable, Realistic Foreign Policy,” Czech News Agency (6 September 2007).

40 Roger Cohen, "For Europe, a Moment to Ponder," International Herald Tribune (27 March 2007), 4.

41 Ibid.

42 A European poll found that only 23 percent of citizens were willing to accept higher levels of defense spending; TNS-Sofres survey data are available at www.openeurope.org.uk/mediacentre/pressrelease. aspx?pressreleaseid=36.

43 “Poland Moots EU Army Tied to NATO,” The Financial Times.com (6 November 2006), 8. 
wrong to fail to share missile defense between NATO powers and Russia, although later he stated that the technology was a waste of money. ${ }^{44}$ Moreover, Moscow is embarking on a new series of intercontinental ballistic missiles and nuclear submarines, the former at a rate of seventeen per year, a substantial increase from the usual number of four. The missiles in question, the Topol-M class, are pointedly described by Putin as able to penetrate any missile defense system. Ivanov also stated that the "combat readiness of the army and navy is currently the highest in the post-Soviet history," and he wanted to "exceed Soviet era levels." 45 Given current tendencies in Russian politics, his statements appeared even more dangerous to countries like Poland.

From Putin on down, Russian reactions to the proposed missile defense system have grown steadily less diplomatic. It is vital to note that the Russians are particularly upset that the eastern NATO members - those that made promises to station no offensive weapons after joining NATO—are the location for these new bases. These countries seem to be containing Russia, as "the process of NATO expansion has nothing to do with the modernization of the Alliance. We have the right to ask, against whom is this expansion directed?" 46 As Georgy Bovt notes, the problem is that the Kremlin is convinced that the U.S. has a long-term plan to subjugate Russia through measures like missile defense and interference in areas like Georgia, and this reaction is deeply felt by most politicians in Russia, most of whom have roots in the old Soviet government. The original Reagan-era SDI program was very alarming to Soviet elites, for despite its technical limitations, it was a system that they could never hope to match; in short, it was an unanswerable challenge to a backward economic system. These same people therefore retain strong feelings today on this issue, despite many statements from the United States pointing out how such a small system could not possibly change the strategic balance. ${ }^{47}$ President Bush, for example, has recently attempted to convince President Putin directly that the BMD system has limited ends that are not directed at his country, as has Secretary of State Rice in several visits to Moscow. Yet such reassurances will probably not work. According to Russian political scientist Vladimir Shlapentokh, anti-Americanism serves a psychological role in justifying the failures of the post-Soviet years, even if there is no objective reason for fear. It serves as a rallying cry to unify the upper classes against a common enemy, and has now become embedded in the national culture. ${ }^{48}$

Essentially, the Russians do not believe the system is as benign as the U.S. portrays it to be, echoing their original fears of the 1980s SDI program. In their view, agreements made at the end of the Cold War were methods used to encourage Moscow to

44 “Russian Defense Minister Calls START Treaty 'Cold War relic',” BBC.com (11 February 2007).

45 “Russia Plans New ICBMs, Nuclear Subs,” Associated Press (7 February 2007).

46 "Putin Says U.S. is Undermining Global Stability," New York Times Online (11 February 2007).

47 Georgy Bovt, “Three Scary Words: SDI,” St. Petersburg Times Online (9 March 2007).

48 Vladimir Shlapentokh, "Russian Attitudes Toward America: A Split Between the Ruling Class and the Masses,” World Affairs 164:1 (Summer 2001). 
lower its guard, and now Russia has the strength to react. For example, the Treaty on Conventional Arms in Europe has now been broken in spirit by the West, as former Warsaw Pact countries not under its jurisdiction are being armed in opposition to Moscow. Now, a ballistic missile defense system based in Central Europe is an economical way to begin to lessen the power of the Russian deterrent in a region that is next door to their vital installations. Such tactics are ironically reminiscent of Khrushchev's attempts to install missiles in Cuba by using friendly allies to contain a nearby superpower.

In the view of the Russian military, anti-ballistic missiles can easily be turned into more threatening platforms for launching attacks because the high-speed weapons involved can be used instead for a decapitating nuclear strike. To quote Lieutenant-General Yevgeny Burzhinsky of the Russian military, such a system will support U.S. rather than greater European interests, and "may pose a direct threat to Russian deterrent forces." In a sense the system is a technological way to trump the collective aspects of NATO by forcing it to confront Russia. ${ }^{49}$ Over time, the Americans will expand the system to the point where the forces of Russia and China will be much less credible as a deterrent because, as nuclear stockpiles diminish due to age and arms control agreements, a U.S. first strike combined with BMD could mean victory in a nuclear war. ${ }^{50}$

These fears have been reflected in Russian pronouncements. Army Chief of Staff Yury Baluyevsky has stated that his country may withdraw from the 1987 Intermediate-range Nuclear Forces Treaty, and specifically mentioned the new BMD bases as a reason for doing so. He echoed Putin's remarks that this agreement was no longer in the Russian national interest, and threatened that a new arms race looms if the bases are built in Central Europe. This threat is especially important in the European context, as these weapons were once targeted at European assets, with German towns for example described as being "one kiloton apart." Putin even stated that missiles launched from North Korea could not be shot down from Poland, stating, "This [approach] clearly contradicts the principles of ballistics. Or as we say in Russia, it's like trying to reach your left ear with your right hand." ${ }^{\text {51 }}$ Finally, the bases are seen as a way to pressure Russia generally, on issues ranging from energy supplies to stopping its influence in former Soviet republics like Georgia.

Even though up to two-thirds of Polish citizens are opposed to the bases, with similar reactions in the Czech Republic, both governments still believe that hosting them is in their national interest. ${ }^{52}$ The bases will be run by U.S. forces and will be extra-territorial, which is also unpopular with the citizenry. Yet the reaction to the most overt threats of all-the decision to target both Poland and the Czech Republic by the

49 Lieutenant-General Yevgeny Burzhinsky, "Ballistic Missile Defense and European Security,” Press Release by the Russian Ministry of Defense (6 October 2006).

50 “A Military Technological Alliance,” Agency WPS (13 February 2007).

51 “Russia May Unilaterally Quit INF Treaty-General Staff,” RIA Novosti (15 February 2007).

52 “Czechs Give Go-ahead for U.S. 'Son of Star Wars’ Base,” The Guardian Online (22 January 2007). 
head of Russia's Strategic Rocket Forces-is consistent with the long-term geopolitical views held in both nations. Central Europeans consider that Putin and his generals have greatly overreached themselves by their abrasive statements, which serves to confirm the wisdom of their alliance with the United States. As one Warsaw spokesperson put it, "The reason is that Putin's true colors were revealed ... everyone could sense his arrogance which is why he provoked little sympathy.” For their part, the Czechs also dismissed Russian threats, stating "they make us more adamant to continue in that direction. We are a sovereign nation...."53

Whether or not the proposed BMD system is technologically sound or economically feasible, the Central Europeans feel that Russia is emerging once again as a threat, and they must ally themselves with the power most likely to do something about it. It is also pertinent to note that prominent Western European politicians, such as the previously mentioned German Foreign Minister Steinmeier, did not criticize Putin's speech, thus confirming Polish suspicions that their EU partners may be more interested in a new Russian gas pipeline than in Moscow's attempts to reassert its sphere of influence. ${ }^{54}$ The impact of history is also ever present, as Russian and Soviet tactics are long remembered by the Central Europeans; as the Czech Foreign Minister stated, "We have quite an experience with the Russians. You have to make it clear to them you won't succumb to blackmail. Once you give in, there is no going back." ${ }^{, 55}$ It is also true that both countries now use their longstanding support for the United States as a source of power in Europe; they are no longer small countries in thrall to the Russians. They have proven themselves willing to make difficult decisions amid criticism from more powerful neighbors, and the United States now turns to them, transcending Old Europe. By embracing both the operation in Iraq and the new BMD bases, their stature has been significantly elevated. ${ }^{56}$ This new status is useful, particularly in confronting a powerful Germany, who has territorial disputes with Poland and may bypass the country with its pipeline to Russia. ${ }^{57}$

\section{Common European Security}

The question of BMD bases is perhaps more profound for the future of common security policy in Europe than is the divide over the conflict in Iraq. This painful war has proven to Western Europeans that their refusal to participate was a wise decision, but now the question at hand concerns security in their own neighborhood. It is also crucial

53 “Putin’s Harsh Speech Is Seen Falling Flat in Europe,” International Herald Tribune (15 February 2007).

54 "Putin Fails to Rally Europe with Critique of U.S.; Despite Rift, Leaders Unswayed by Speech,” International Herald Tribune (16 February 2007), 2.

55 Ibid.

56 “Germany Is Slightly Jealous,” Agency WPS (7 March 2007).

57 President Kaczynski has strong feelings about the territorial claims of some German citizens. He states that the complaints against his country "may have a devastating effect on relations between the two states." See "Polish-German Relations: Claims, Complaints \& Controversy,” The Warsaw Voice (3 January 2007). 
to note that the expansion of Europe via NATO and the EU is making achieving a concerted European defense policy ever more difficult. As Robert Kagan notes, under U.S. protection during the Cold War, Europeans increasingly rejected the concept of force in international relations despite their growing economic power. It may also be true that the Europeans understand the cost of war more than the United States does. However, they must make a choice whether to become a world power or accept U.S. leadership and its ideas. Central Europe is unwilling to accept the EU's heretofore unrealized commitments to common security, and have become frustrated with the lack of concrete action. ${ }^{58}$ For example, the organization has of late failed to agree on a common policy on Iran's nuclear programs, and was unable to arrive at an effort to pressure Iran to release British sailors who were seized while enforcing United Nations mandates. Poland also considers its own opinions of and experience with Russia much better informed to those of the Western Europeans, who have in any case demonstrated their willingness to abandon Central Europe on several bitter occasions in the past. ${ }^{59}$

Again, as in the case of Iraq, both Poland and the Czech Republic think they can differ with their Western counterparts on the BMD question but still reach out to them to arrive at a significant consensus on other concerns. Both countries have disagreed with the United States on issues such as the International Criminal Court, the Comprehensive Test Ban Treaty, and the Kyoto Protocol-all issues of central concern to nations in Western Europe. In short, on vital matters important to European civilization and attitudes on the world, the split in Europe is not so wide. At the same time, these states' willingness to host the bases also anchors the U.S. to the defense of Central Europe, and puts pressure on NATO to move on the new measures. It is also true that, compared with the grandiose plans of the original SDI system, the much smaller BMD proposals have some support in all European governments, as the ability to knock down even a few missiles could save millions of lives. Again, it is more a matter of the way the U.S. is going about this program rather than its intrinsic merits. ${ }^{60}$ Moreover, the Polish and Czech decision to host the bases places pressure on the EU to go beyond vague pronouncements on security. After all, what substantive alternative has this organization implemented concerning Iran and nuclear terrorism?

Has the United States learned from its experience in Iraq that choosing between its allies damages the Alliance, and perhaps long-term Atlantic security as well? At this point, the answer appears negative. This administration seems to be installing these

58 See "EU Pessimistic over Teheran's Nuclear Potential," which basically states that the organization considers it impossible to stop Iran from obtaining nuclear weapons, and has failed to come to an agreement on stricter sanctions. The Telegraph Online (U.K.) (14 February 2007).

59 Robin Shepard, “ Romania, Bulgaria, and the EU’s future,” Current History (March 2007): 117-22.

58 “Europe Warms to U.S. Missile Shield,” Christian Science Monitor (26 February 2007), 1.

59 Jonathan Rauch, “Coalition of the Waiting,” The Atlantic Monthly (December 2006), 29-30.

60 "Russia’s response is totally political,” says one Russian analyst, quoted in Rauch, "Coalition of the Waiting." 
bases without thoughtfully considering their impact on the United States' longtime allies. However, the difference between this situation and the operation in Iraq is that there seems to be genuine fear of a frequently bellicose Iran, as both European and American citizens are alarmed at the prospect of this nation acquiring weapons of mass destruction, leading to a greater degree of consensus than on Saddam's Iraq. So, while Europeans debate the undiplomatic way the U.S. wants to install the missile bases, and may be angered that their Eastern cousins agreed so quickly, they are still aware of the need for action. Iran's actions and belligerent statements show no real sign of abatement. Hopefully a new, more diplomatic U.S. administration can fully discuss with Europe the best options for dealing with potential new members of the nuclear club, which might well involve relatively small missile defense systems. However, other options might be attempted as well, such as a renewed commitment to the principles of the Non-Proliferation Treaty, with the United States participating in verifiable builddowns of its deterrent force and renewed commitments against first strikes. Working with the United Nations in non-proliferation efforts would also be popular with the Europeans, on both ends of the continent. In addition, these efforts would be more fruitful in moderating Russian actions, which at present seem to echo the Cold War. There are some who claim that politicians there are merely using fear about the antimissile bases to mobilize domestic support, even though they know the system is miniscule. Yet, even if this claim is true, a more sensitive U.S. policy might moderate internal Russian politics, another goal that the West should pursue. 
FALL 2008

\section{Bibliography}

Huntington, Samuel. "The Lonely Superpower." Foreign Affairs 78, no. 2 (1999).

Kagan, Robert. Of Paradise and Power: America and Europe in the New World Order. New York: Alfred Knopf, 2003.

Kole, William. "U.S.: Defense Shield No Threat to Russia." Associated Press (2007).

Rauch, Jonathan. "Coalition of the Waiting." The Atlantic Monthly (2006).

Ray, Leonard, and Gregory Johnson. "European Anti-Americanism and Choices for a European Defense Policy." Political Science (2007).

Wayne, Merry. "Therapy's End: Thinking Beyond NATO." The National Interest (2003). 